\title{
Gravimetric Study of Geological Structures of Teboursouk Area, Northern Tunisia
}

\author{
Amira Ayed-Khaled ${ }^{1 *}$, Taher Zouaghi ${ }^{2}$, Mohamed Ghanmi ${ }^{1}$, Fouad Zargouni ${ }^{1}$ \\ ${ }^{1}$ Département des Sciences de la Terre, FST, Université Tunis El Manar, Tunis, Tunisia \\ ${ }^{2}$ Laboratoire de Géoressources, CERTE, Pôle Technologique de Borj Cédria, Université de Carthage, Soliman, Tunisia \\ Email: *ammoura.khaled@gmail.com
}

Received March 15, 2012; revised April 20, 2012; accepted April 28, 2012

\begin{abstract}
Gravity data associated with surface geology in the Northern Tunisian Atlas offer better understand to the underlying structures in Teboursouk area and to highlight other deep or unknown structures in surface. The gravity study was based on qualitative and quantitative analysis including the construction of the gravity Bouguer anomaly, upward continuations, residual anomaly, and Horizontal gradient maxima maps. The main results display many positive and negative anomalies as the response of geological structures (J. Cheid Triassic structure, Khalled plain, El Aroussa plain). In addition, the horizontal gradient maxima integrated with geological and structural maps let the identification of major directions of gravimetric lineaments in the study area us NE-SW trending features at the boundaries of J. Cheid structure, NW-SE direction that limit Gaafour plain and Tabet Ech Cherif syncline, and N-S trending that bordered El Aroussa basin. Major results allowed the construction of a new structural map of the study zone.
\end{abstract}

Keywords: Gravimetry; Bouguer Anomaly; Upward Continuations; Gradient; Structure; Northern Tunisia

\section{Introduction}

The geodynamic evolution and geometry of the Mediterranean basins has been related to different spreading rates along the Atlantic oceanic ridge [1,2]. Since the Late Triassic to Present, the north African domain has undergone episodes of deformation that can be correlated to plate kinematics; these movements are fossilized in the sedimentary deposits $[3,4]$. The Septentrional Atlas highlights paleogeographic continuity and records tectonic and sedimentary events follow the major orogenic phases, which are the consequence of the convergence movements between the African and Eurasiatic plates [1,4-10]. These are followed by compressive tectonic constraints beginning in the end of Late Cretaceous times [1,11-16] and has created many chains and mountains in the Mediterranean borders. The various geological studies concerning Northern Tunisia and the Siculo-Tunisian strait [4, 17-24] shows the importance effect of the NE-SW, NW-SE and north-south faults on the control of sedimentation associated to the structuring of these domains (Figure 1). On the other hand, the Triassic rifting phase characterized by the rejuvenation of NE-SW hercynian faults was continued during the Jurassic and the Early Cretaceous time $[4,25,26]$, and records in northern Tunisia the formation of grabens and synclines separated by

${ }^{*}$ Corresponding author. horsts structures. Several other lineaments oriented NESW (Tunis-Ellès and El Alia-Teboursouk faults) has an important control on the sedimentary distribution during this same period. After a short Aptian-Early Albian transpressional period, NE-SW to ENE-WSW trending extensions prevailed during the Late Cretaceous. It is regionally identified through the Tunisian Atlas $[3,4,20,27$ 29]. The tectonic movement with vertical component was associated with rising of the Triassic material along a basement opening major faults or fault systems. During Cenomanian period, is a second extensional event that has continued in the study domain [3,14,29-35]. The Late Cretaceous extensions affected the whole Northeastern African margin, originating NW-SE to NNW-SSE striking basins $[3,14,36]$. From the Cenomanian to the Early Maastrichtian times, was the same regional NE-SW extension. The inversions started in Late MaastrichtianPaleocene in Northern Tunisia, which constitutes a first compressional event. A second and major compressional event resulting in significant inversions of Mesozoic basins occurred in the Late Eocene (Atlassic phase). The Triassic domes and the diapirs zones are generally lengthened NE-SW [28,37].

\section{Geological Setting}

The study area (Teboursouk) is located in the northern Tunisian Atlas. Teboursouk map (Teboursouk 1/50,000 
sc. Map) [38] contains major salt alignments (Figure 2) J. Cheid-Knana, which is the larger outcrop, Fej LahdoumAin Jemmala, and Thibar structures. The studied area is composed of two main sedimentary series. The Mesozoic strata comprise Triassic material composed by chaotic deposits including salt layers $[3,39,40]$. The Jurassic and the Lower Cretaceous deposits display no outcrops in the area. The Early Cretaceous strata are composed of Late Aptian-Early Albian sediments with black clayey marls. In addition, the Late Cretaceous is represented by Cenomanian (marls) to Senonian series (limestones and marls) [28,41]. The Cenozoic deposits (Paleocene to Oligocene time) are composed of marls, limestones, and sandstones. The Neogene formation is composed of Miocene marls.

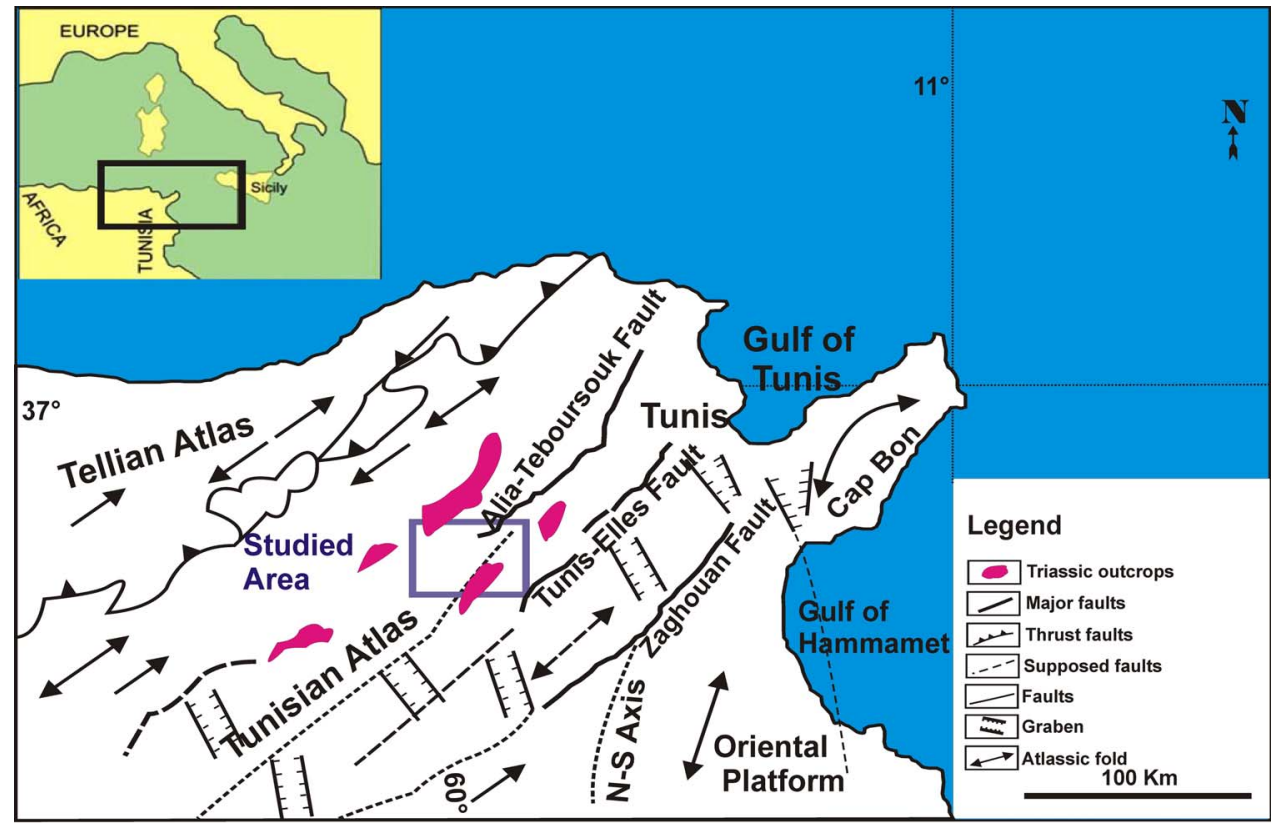

Figure 1. Geographic and geological location of the studied area in the Mediterranean domain [4,20,27-29].

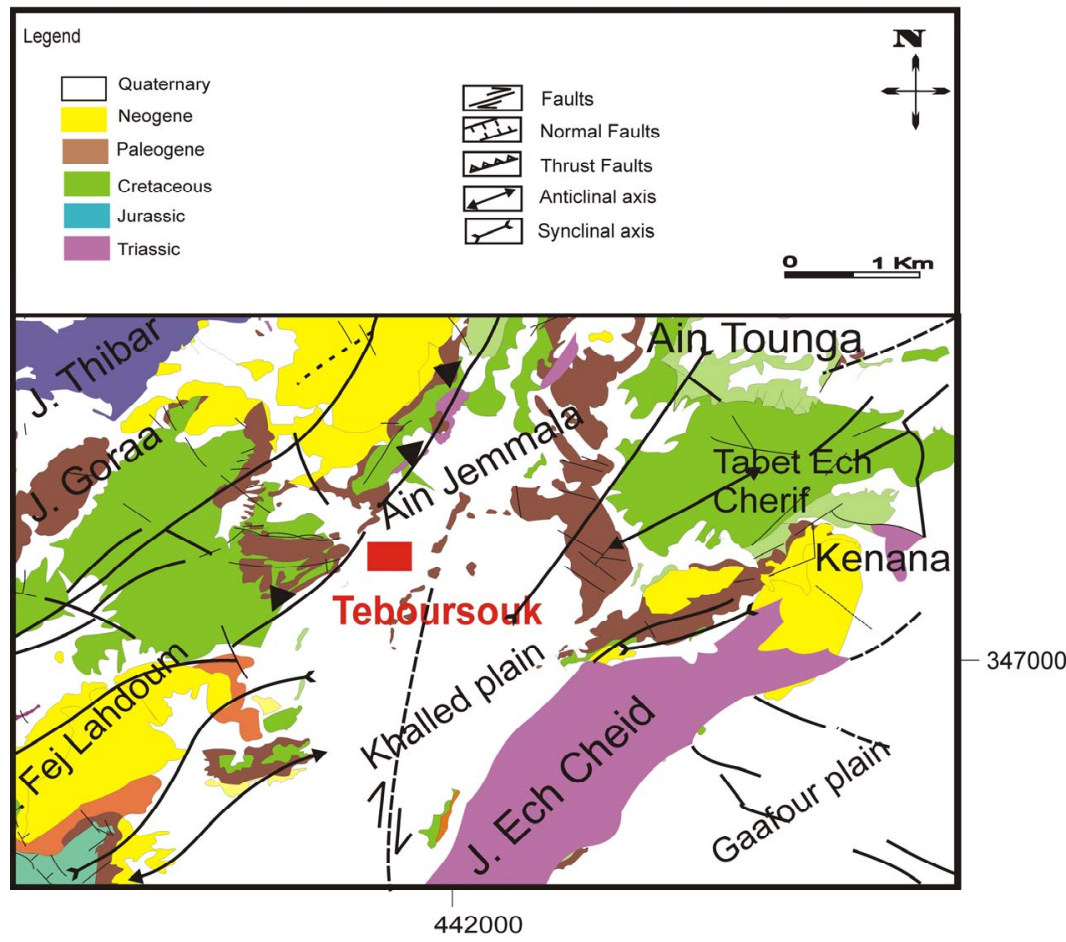

Figure 2. Simplified geological and structural map of the study area [38, completed and modified]. 
The Pliocene-Quatenary series shows a conglomeratic beds on the base and of sandy clay ones on the top [35, 41-46].

\section{Gravity Data}

In our study, we used gravity data in the northern Tunisian Atlas collected by the Office National des Mines (ONM) [46] (gravimetric map of Teborsouk area). The studied area is covered by gravity stations on a $1 \times 1 \mathrm{~km}^{2}$ grid. The data were gridded at a spacing of $1 \mathrm{~km}$ using a minimum curvature technique Briggs, (1974) [47], and contoured at a $1 \mathrm{mGal}$ interval to establish a complete Bouguer anomaly map. This map reflects generally the lateral variations of density in the subsurface associated to the geological structures.

\section{Gravity Data Analysis}

\subsection{Bouguer Anomaly}

The complete gravity anomaly map (Figure 3) has much information on present discontinuities in the basement, which can be extracted by analyzing pressure gradients between anomalies [48-50]. The complete Bouguer gravity anomaly values range from -20 mGals in the southeast to $18 \mathrm{mGals}$ in the northeast. Indeed, Figure 3 shows positives anomalies such as: a NE-SW anomaly that coincides with Triassic bodies from the J. Cheid, a E-W anomaly that corresponds to a Cretaceous series of Tabet Ech Cherif, a NE-SE anomaly associated with a Triassic alignment of J. Cheid-Knana, and finally a cretaceous outcrops of Oued Arkou anticline and the south part of J. Thibar. These positive anomalies are bounded by two other negative anomalies associated with Gaafour, and Khalled plains composed of quaternary deposits.

In order to separate shallow sources, the residual ano- maly was obtained by subtracting the regional field to the Bouguer anomaly. For this reason, upward continuation method was used to constrain regional map [50-54]. The upward continuation of the Bouguer anomaly to $20 \mathrm{~km}$ of altitude expresses a very smooth gravity pattern, a big positive anomaly in the NE part of the map (Cretaceous series) and negative anomaly in the south (plains with quaternary sediments) (Figure 4).

\subsection{Residual Anomaly}

The residual map (Figure 5) expresses various gravity anomalies with values ranging between $20 \mathrm{mGals}$ in the northeastern part of the map, to -10 mGals in southeastern part that coincides with Gaafour plain. Positive anomalies are placed from the eastern part to western part of the study area, they corresponds to a Cretaceous series of Tabet Ech Cherif, Triassic alignment of J. Cheid-Knana, Oued Arkou anticline, and the south part of J. Thibar. Negative anomalies correspond to Gaafour and Khalled plains. NE-SW-direction curves indicate a gravity gradient decreasing laterally over the Khalled and Gaafour plains in quite coherence with the nature distributions in rock densities.

\subsection{Horizontal Gradient Maxima}

In order to delineate lineaments associated with boundaries of rock units or faults [49,50-52] the horizontal gradient maxima method is applied on the Bouguer anomaly map. In this case, lineated contacts correspond to faults, while the circular contacts are the limits of diapirs or of intrusive bodies.

Gravity anomaly over a vertical contact is realized by a curve having a minimum for a weak density rocks and a maximum for a high density rocks [48-50]. The inflexion point of the curve is in the equilibrium of this contact

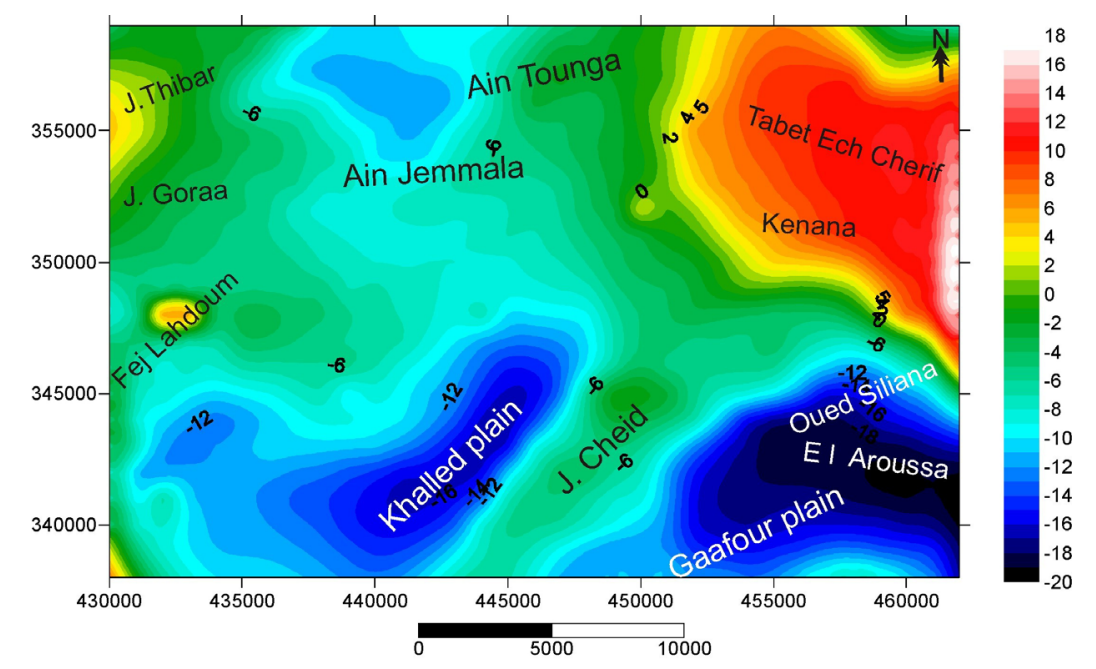

Figure 3. Bouguer anomaly map (minimum contouring interval is $1 \mathrm{mGal}$; coordinates are in kilometres). 


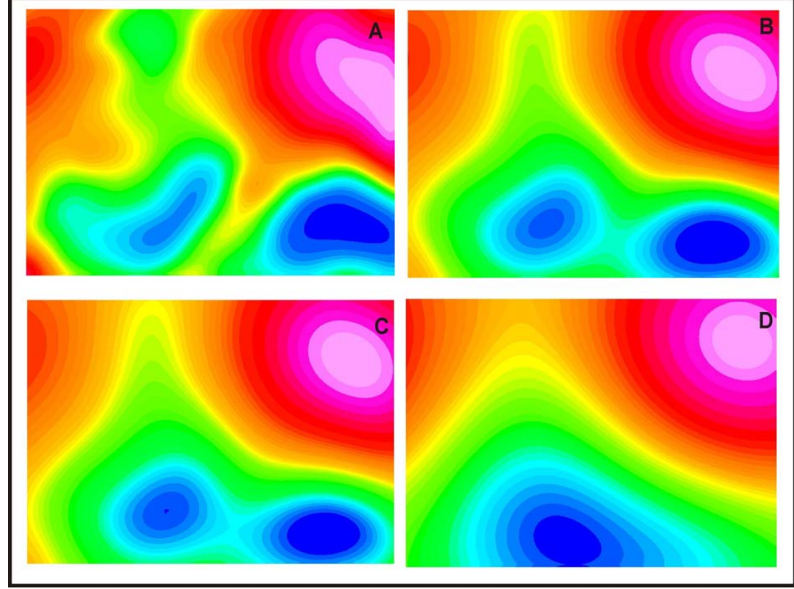

Figure 4. Upward continuation map to different heights: (a) 1000 m; (b) 5000 m; (c) 10,000 m; (d) 20,000 m.

showing the maximum of the horizontal gradient. If a contact has no vertical dip, the maxima of the horizontal gradient move in the dipening, but, these will stay near this contact for high dip.

Blackely and Simpson [53] (1986) proposed a new method to determine the horizontal gradient maxima. The dip of various contacts is determined by the upward continuation of Bouguer anomaly map. At every level, the horizontal gradient maxima are localized. Thus, the highest levels of continuation correspond to the deepest contacts and vice versa. If we have a vertical structure, all the maxima overlap.

The Horizontal gradient maxima map (Figure 6) reveals the existence of NE-SW and NW-SE direction, in the study area. This carte shows thin alignments; the most significant are those of the J. Cheid outcrop that reflect a net contrast of density between the Triassic and surrounding cretaceous series. Gradients are more im- portant in the Northern part of this structure, than the South part. In addition, two lineaments with NW-SE direction bordered El Aroussa plain and associated with quaternary deposits [54]. This result is well confirmed by the Figure 7. This map (Figure 7) is obtained from superimposing the interpreted gravimetric faults to a geological map of the study zone. It reveals the existence of variety of directions that correspond to the boundaries of structure; NE-SW, NW-SE and N-S with dominance of $\mathrm{NE}$ oriented alignments.

\section{Discussion and Conclusions}

The superimposing of gravimetric lineaments map on the structural map of the study area shows an important fracturing in the sedimentary coverage especially to Tabet Ech Cherif, J. Cheid and in Ain Tounga zones (Figure 7).

Several directions were highlighted:

- NE-SW Direction characterized by faults of great dimensions and an strong dip that limit especially $\mathrm{J}$. Cheid (F1) and Ain Jemmala (F3) Triassic outcrops, and the south of Oued Siliana (F2).

- E-W Direction that constitutes a network of faults from the North to the South: the fault F4 of Oued Siliana with a dip towards the north, F5 cutting the J. Cheid Triassic outcrop, F6 from Koudiat Basina Serira to the North of J. Strassif and F7 in the south part of Gaafour plain (Figure 7).

- NS Direction which contains several faults: the fault F8 in El Aroussa plain and F9 between the two synclines of Tabet Ech Cherif and Ain Tounga.

- NW-SE Direction represented especially by the new lineament of Tabet Ech Cherif with a SW dip syncline (F10) and F11 that limit Gaafour plain (Figure 7).

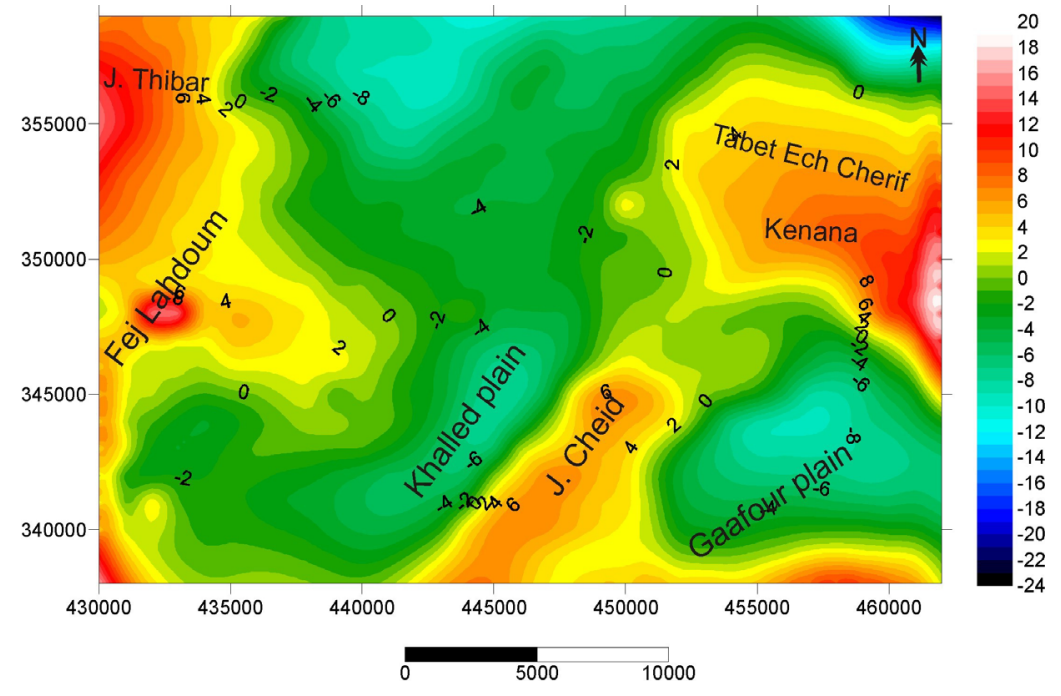

Figure 5. Map of the residual anomalies in the Teboursouk area. 


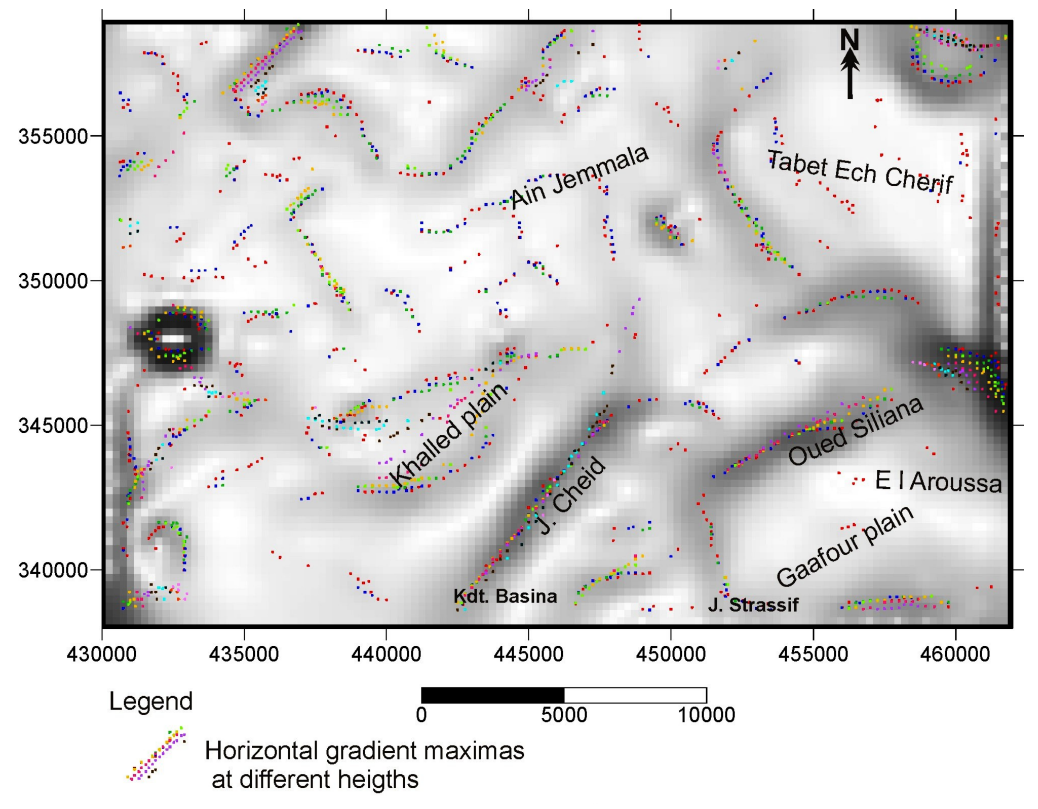

Figure 6. Maxima of the horizontal gradient of the Bouguer anomaly and its upward continuation to different heights superimposed on the horizontal gradient, showing the interpreted gravimetric lineaments in the study area.

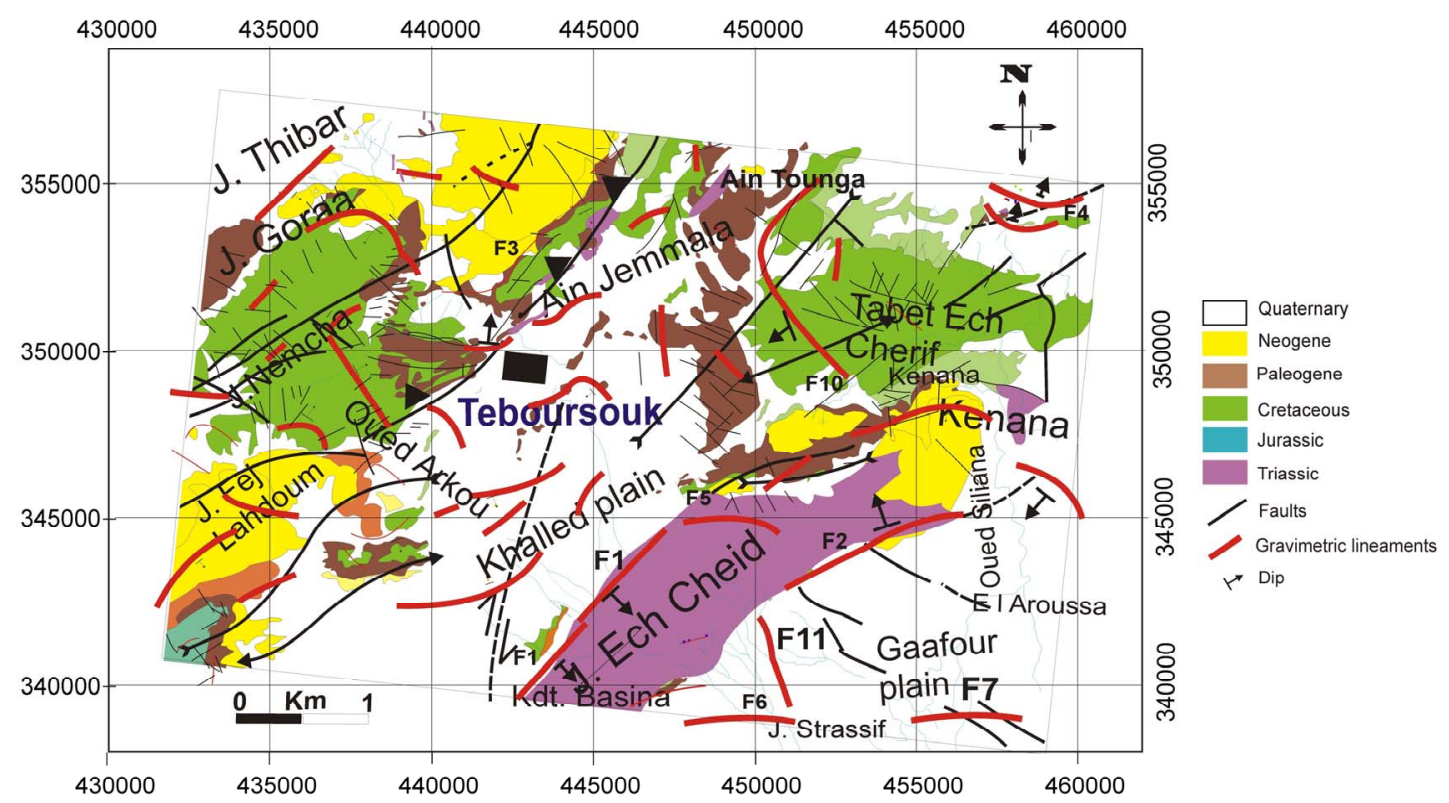

Figure 7. Interpreted structural map of Teboursouk area superimposed on the geological map of Perthuisot et al., 1978.

Additionally, the result map (Figure 7) shows that Triassic outcrops of J. Cheid and Kenana are separated by a depression. It is not a same structure.

Some gravimetric lineaments coincide perfectly with observed geologic faults. These faults put in contact grounds with different densities and are normally deep. Other gravimetric lineaments such as F4 and F9 are unknown and haven't signature in surface, represent one of the new contributions of this study, because these faults must be masked in the surface.

\section{REFERENCES}

[1] R. Guiraud, "Mesozoic Rifting and Basin Inversion along the Northern African Tethyan Margin: An Overview," In: D. S. Macgregor, R. T. J. Moody and D. D. Clark-Lowes, Eds., Petroleum Geology of North Africa-Geological Society, Special Publication, London, No. 132, 1998, pp. 217-229.

[2] A. Piqué, L. Ait Brahim, R. Ait Ouali, M. Amrhar, M. Charroud, C. Gourmelen, E. Laville, F. Rekhiss and P. Tricart, "Evolution Structurale des Domaines Atlasiques du Maghreb au Méso-Cénozoïque; le Rôle des Structures 
Héritees dans la Déformation du Domaine Atlasique de l'Afrique du Nord," Bulletin de la Societe Geologique de France, Vol. 169, 1998, pp. 797-810.

[3] S. Bouaziz, E. Barrier, M. Soussi, M. M. Turki and H. Zouari, "Tectonic Evolution of the Northern African Margin in Tunisia from Paleostress Data and Sedimentary Record," Tectonophysics, Vol. 357, No. 1-4, 2002, pp. 227-253. doi:10.1016/S0040-1951(02)00370-0

[4] F. Melki, T. Zouaghi, M. Ben Chelbi, M. Bédir and F. Zargouni, "Tectono-Sedimentary Events and Geodynamic Evolution of the Mesozoic and Cenozoic Basins of the Alpine Margin, Gulf of Tunis, North-Eastern Tunisia Offshore," Compte Rendus Geoscience, Vol. 342, No. 9, 2010, pp. 741-753.

[5] B. Biju-Duval, J. Dercourt and X. Le Pichon, "From Tethys Ocean to the Mediterranean Sea," In: B. BijuDuval and L. Montadert, Eds., Structural History of the Mediterranean Basin, 1977, pp. 143-164.

[6] M. Durand-Delga, "La Méditerranée Occidentale: Etapes de sa Genèse et Problèmes Structuraux Liés à Celles-ci," Société Géologique de France, Vol. 10, 1980, pp. 203224.

[7] P. Casero and F. Roure, "Neogene Deformation at the Sicilian-North African Plate Boundary," In: F. Roure, Ed., Peri-Tethyan Platforms, Editions Technip, Paris, 1994, pp. 27-50.

[8] J. P. Bouillin, et al., Compagnes SARCYA et SARTUCYA, "Le Canal de Sardaigne, à la Croisée des Bassins Algéro-Provençal et Tyrrhénien de la Méditerranée et des Segments Kabylo-Tunisiens et Siculo-Calabrais de la Chaine des Maghrébides, Africain Continental Margins of the Mediterranean Sea-Djerba," CIESM Workshop Series No. 10, 2000, pp. 49-51.

[9] L. Torelli, G. Carrara, R. Sartori and N. Zitellini, "Cenozoic Collisional and Extensional Structures among Sardinia, Sicily and Tunisia (Central Mediterranean): Examples and Constraints from Seismic Reflection Profiles," African Continental Margins of the Mediterranean SeaDjerba, CIESM Workshop Series No. 10, 2000, pp. 53-55.

[10] P. Casero, "Structural Setting of Petroleum Exploration Plays in Italy," In: Crescenti et al., Eds., Geology of Italy: Societa Geologica Italiana, Special Volume, 2004, pp. 189-200.

[11] W. Alvarez, "Tectonic Evolution of the Corsica-Apennines-Alps Region Studied by the Method of Successive Approximations," Tectonics, Vol. 10, No. 5, 2004, pp. 936-947. doi:10.1029/91TC00232

[12] P. Tricart, L. Torelli, G. Brancolini, M. Croce, L. De Santis, D. Peis and N. Zitellini, "Dérives d'Arcs et Dynamique Méditerranéenne Suivant le Transect Sardaigne-Afrique," Compte Rendus de l'Académie des Sciences, Vol. 313, 1991, pp. 80-806.

[13] C. Doglioni, E. Guegue, P. Harabaglia and F. Mongelli, "On the Origin of the West-Directed Subduction Zones and Applications to the Western Mediterranean, the Mediterranean Basins: Tertiary Extension within the Alpine Orogen," In: B. L. Jolivet, F. Horvath and M. Seranine, Eds., Geological Society, London, 1999, pp. 541561.
[14] H. El Euch, M. Saidi, L. Fourati and C. El Mahersi, "Northern Tunisia Thrust Belt: Deformation Models and Hydrocarbon Systems," In: R. Swennen, F. Roure and J. W. Granath, Eds., Deformation, Fluid Flow, and Reservoir Appraisal in Foreland Fold and Thrust Belts, AAPG Hedberg Series No. 1, 2004, pp. 371-390.

[15] G. H. Mascle, P., Tricart, L. Torelli, J.-P. Bouillin, R. Compagnoni, S. Depardon, J. Mascle, A. Pecher, D. Peis, F. Rekhiss, F. Rolfo, H. Bellon, G. Brocard, H. Lapierre, P. Monie and G. Poupeau, "Structure du Canal de Sardaigne: Réamincissement Crustal et Extension Tardiorogénique au Sein de la Chaîne Apennino-Maghrébienne; Résultats des Campagnes de Plonge' es Cyana SARCYA et SARTUCYA en Méditerraneé Occidentale," Bulletin de la Societe Geologique de France, Vol. 175, No. 6, 2004, pp. 607-627. doi:10.2113/175.6.607

[16] D. Frizon de Lamotte, A. Michard and O. Saddiqi, "Quelques Développements Récents sur la Géodynamique du Maghreb," Compte Rendus Geoscience, Vol. 338, 2006, pp. 1-10.

[17] P. F. Burollet, "Etude Géologique des Bassins Mio-Pliocènes du Nord-est de la Tunisie," Annale des Mines et de Géologie, Vol. 7, 1956, 91 p.

[18] A. Jauzein, "Contribution a l'Etude Géologique des Confins de la Dorsale Tunisienne (Tunisie Septentrionale)," Annale des Mines et de Géologie, Vol. 22, 1967, 475 p.

[19] T. Zouaghi, M. Bédir, F. Melki, H. Gabtni, R. Gharsalli, A. Bessioud and F. Zargouni, "Neogene Sediment Deformations and Tectonic Features of Northeastern Tunisia: Evidence for Paleoseismicity," Arabian Journal of Geosciences, Vol. 4, No. 7-8, 2010, pp. 1301-1314. doi:10.1007/s12517-010-0225-Z

[20] N. B. Ayed, "Evolution Tectonique de l'Avant-Pays de la Chaîne Alpine de Tunisie du Début du Mésozoïque à l'Actuel," Annale des Mines et de Géologie, Editions du Service Géologique de Tunisie, No. 32, 1993, 286 p.

[21] L. Chihi and H. Philip, “Les Fossés de l'Extrémité Orientale du Maghreb (Tunisie et Algérie Orientale): Tectonique Mio-Plio-Quaternaire et Implication dans l'Evolution Géodynamique Récente de la Méditerranée Occidentale," Notes Service Géologique, Vol. 64, 1998, pp. 103-116.

[22] R. Sartori, G. Carrara, L. Torelli and N. Zitellini, "Neogene Evolution of the South-Western Tyrrhenian Sea (Sardinia Basin and Western Bathyal Plain)," Marine Geology, Vol. 175, No. 1-4, 2001, pp. 47-66. doi:10.1016/S0025-3227(01)00116-5

[23] M. B. Chelbi, F. Melki and F. Zargouni, "Mode de Mise en Place des Corps Salifères dans l'Atlas Septentrional de Tunisie. Exemple de l'Appareil de Bir Afou," Compte Rendus Geoscience, Vol. 338, No. 5, 2006, pp. 349-358. doi:10.1016/j.crte.2006.02.009

[24] F. Rekhiss, "Modèle d'Evolution Structurale et Géodynamique à l'Extrémité Orientale de la Chaîne Alpine d'Afrique du Nord," Thèse d'Etat en Géologie, Université de Tunis El Manar, 2007, 285 p.

[25] M. M. Turki, "Polycinématique et Contrôle Sédimentaire Associés sur la Cicatrice Zaghouane-Nabhana," Vol. 7, Institut National de Recherche Scientifique, Tunisie, 1988, 
$252 \mathrm{p}$.

[26] M. Soussi, "Nouvelle Nomenclature Lithostratigraphique 'Evènementielle' pour le Jurassique de la Tunisie Atlasique," Geobios, Vol. 36, No. 6, 2003, pp. 761-773. doi:10.1016/j.geobios.2003.03.001

[27] F. Zargouni, "Etude des Mouvements Ascensionnels du Complexe Triasique dans la Chaîne de Lansarine (Atlas Tunisien-Zone des 'Diapirs'," Notes du Service Géologique, Tunisia, Vol. 43, 1977, pp. 13-21.

[28] V. Perthuisot, "Dynamique et Pétrogenèse des Extrusions Triasiques en Tunisie Septentrionale," École Normale Supérieure Paris, Paris, 1978, 312 p.

[29] M. Ghanmi, M. B. Youssef, M. Jouirou, F. Zargouni and J. M. Vila, "Halocinèse Crétacée au Jebel Kebbouch (Nord-Ouest Tunisien): Mise en Place à Fleur d'Eau et Evolution d'un 'Glacier de Sel' Albien, Comparaisons," Eclogae Geologicae Helvetiae, Vol. 94, 2001, pp. 153160.

[30] N. Boukadi, "Structuration de l'Atlas de Tunisie: Signification Géométrique et Cinématique des Noeuds et des Zones d'Interférences Structurales au Contact de Grands Couloirs Tectoniques," Ph.D. Thesis, University of Tunis El Manar, Tunis, 1994.

[31] M. Bédir, "Mécanismes Géodynamiques des Bassins Associe's aux Couloirs de Coulissement de la Marge Atlasique de la Tunisie," Ph.D. Thesis, University of Tunis El Manar, Tunis, 1995.

[32] N. Ben Ayed, "Les Décrochements-Chevauchements de la Tunisie Septentrionale: Géométrie et Essai de Reconstitution des Conditions de Déformations," ETAP, 1998.

[33] J. M. Vila, M. B. Youssef, S. Bouhlel, M. Ghanmi, S. Kassaa and F. Miaadi, "Réponse aux Commentaires de H. Rouvier et al. à la Note 'Tectonique en Radeaux au Toit d'un Glacier de Sel' Sousmarin Albien de Tunisie du Nord Ouest: Exemple du Secteur Minier de Gueurn Halfaya," Compte Rendus de l'Académie des Sciences, Paris Ser., IIa 327, 1998, pp. 563-570.

[34] M. Hammami, "Tectonique, Halocinèse et Mise en Place de la Minéralisation dans la Zone des Diapirs (Tunisie Septentrionale)," Ph.D. Thesis, University of Tunis El Manar, Tunis, 1999, 213 p.

[35] H. El Ouardi, "Origine des Variations Latérales des Dépôts Yprésiens dans la Zone des Dômes en Tunisie Septentrionale," Compte Rendus Geoscience, Vol. 334, 2002, pp. 141-146.

[36] M. Chikhaoui, A. L. Maamouria, J. Salaj, M. M. Turki, J. Saadi, M. Ben Youssef, M. Ghanmi and M. Zarbouta, "Tilted Blocks during the Early Cretaceous in the Le Kef Area (North-Western Tunisia)," Compte Rendus de l'Académie des Sciences de Paris, Vol. 327, 1998, pp. 265270.

[37] H. Rouvier, “Géologie de l'Extrême Nord Tunisien: Tectonique et Paléogéographie Superposées à l'Extrémité Orientale de la Chaîne Nord Maghrébine," Thèse d'Etat, Université Pierre-et-Marie-Curie, Paris, 1977, 898 p.

[38] V. Perthuisot, "Carte Géologique de Téboursouk au 1/50000," Direction des Mines et de la Géologie, Ministère de l'Industrie des Mines et l'Energie, Tunisie, 1978.
[39] M. B. H. ALI, "Etude Géologique du Jebel Goraa (Région de Téboursouk, Atlas Tunisien)," Ph.D. Thesis, Université Paris VI, Paris, 1979, 120 p.

[40] S. Adil, "Dynamique du Trias dans le Nord de la Tunisie: Bassins en Relais Multiples de Décrochement, Magmatisme et Implication Minière," Ph.D. Thesis, University of Tunis el Manar, Tunis, 1993, 249 p.

[41] M. M. B. Slama, A. Masrouhi, M. Ghanmi, M. B. Youssef and F. Zargouni, "Albian Extrusion Evidences of the Triassic Salt and Clues of the Beginning of the Eocene Atlasic Phase from the Example of the Chitana-Ed Djebs Structure (N. Tunisia): Implication in the North African Tethyan Margin Recorded Events, Comparisons," Compte Rendus Geoscience, Vol. 341, No. 7, 2009, pp. 547556. doi:10.1016/j.crte.2009.04.007

[42] M. Solignac, "Les Recherches de Pétrole en Tunisie," Revue de Pétrole, Paris, 1927, 59 p.

[43] K. Daly, "Position Tectonique du Bassin Néogène de Jendouba," Premier Congrès National des Sciences de la Terre Tunis, Tunis, 1981, pp. 321-331.

[44] A. Masrouhi, M. Ghanmi, M. B. Youssef, F. Zargouni and J. M. Vila, "Mise en Evidence d'un Dais de Sel (Salt Canopy) au Jebel Lansarine (Tunisie du Nord): Implication sur la Diversité des Appareils Salifères de la Marge Passive du Nord-Est du Maghreb," 3ème Séminaire National de Stratigraphie, Laghouat, 2007.

[45] F. B. Mehrez, J. Kacem and M. Dlala, "Late Cretaceous Synsedimentary Diapirism of Bazina-Sidi Bou Krime Triassic Evaporites (Northern Tunisia): Geodynamic Implications," Compte Rendus Geoscience, Vol. 341, No. 1, 2009, pp. 78-84. doi:10.1016/j.crte.2008.11.001

[46] I. Hamdi-Nasr, M. H. Inoubli, A. B. Salem1, S. Tlig and A. Mansouri, "Gravity Contributions to the Understanding of Salt Tectonics from the Jebel Cheid Area (Dome Zone, Northern Tunisia)," Geophysical Prospecting, Vol. 57, No. 4, 2009, pp. 719-728.

[47] ONM, "Gravimetric Map of Teboursouk Area," Office National des Mines, Tunisia, 1997.

[48] I. Briggs, "Machine Contouring Using Minimum Curvature," Geophysics, Vol. 39, No. 1, 1974, pp. 39-48. doi:10.1190/1.1440410

[49] L. T. A. Vanié, D. Khattac and M. R. Houari, "Apport des Filtrages des Anomalies Gravimétriques à l'Etude des Structures Profondes du Maroc Oriental," Bulletin de l'Institut Scientifique, Rabat, Section Sciences de la Terre, Vol. 27, 2005, pp. 29-40.

[50] D. Khattach, P. Keating, E. M. Mili, T. Chennouf, P. Andrieux and A. Milhi, "Apport de la Gravimétrie à l'Etude de la Structure du Bassin des Triffa (Maroc nord-Oriental): Implications Hydrogéologiques," Compte Rendus Geoscience, Vol. 336, 2004, pp. 1427-1432.

[51] A. Ayed, M. Ghanmi, M. Gassmi M. M. B. Slama, "Apport de la Gravimétrie dans la Mise en Evidence de Nouveaux Linéaments Structuraux dans la Région de l'Oued Zarga, Massif de Thibar, Tunisie Septentrionale," 3rd Magrebin Colloquium of Applied Geophysics, 2006, pp. 167-168.

[52] J. Schoeffler, "Gravimétrie Appliquée aux Recherches 
Structurales et à la Prospection Pétrolière et Minière," Technip, Paris, 1975, 288 pp.

[53] R. J. Blakely, "Potential Theory in Gravity and Magnetic Applications," Cambridge University Press, Cambridge, 1996.
[54] R. Blakely and R. Simpson, "Approximating Edges of Sources Bodies from Magnetic or Gravity Anomalies," Geophysics, Vol. 51, No. 7, 1986, pp. 1494-1498 doi:10.1190/1.1442197 